\title{
German Ethics Council on genetic diagnostics: trend setting?
}

\author{
Bianca Buechner ${ }^{\star 1}$
}

On 30 April 2013, the German Ethics Council ('Council') published its opinion on 'The future of genetic diagnostics-from research to clinical application' ('the Opinion'). The Council was asked by the German government to discuss the future of genetic diagnostic methods in relation to the current applicable laws and regulations as well as the ethical stand points. The Council's 23 recommendations show that the existing regulations in Germany, and indirectly on a European level, lack in protecting consumers sufficiently. Consumer protection built the major focus of the Council's opinion. However, the opinion misses a critical overall analysis of genetic testing and, for example, the potential misuse of genetic test results by insures or the risk of disclosure toward employers. The Council missed an opportunity to discuss which barriers are necessary from a legal and ethical perspective but which still do not prohibit genetic testing and research.

European Journal of Human Genetics (2014) 22, 831-832; doi:10.1038/ejhg.2013.239; published online 30 October 2013

Keywords: gen testing; bioethics; law; german ethics council

Genetic analysis, genetic testing, direct-to-consumer genetic testing and pre-implantation diagnostics are examples of some of the fastest growing areas in science that may be used as a part of personalized medicine in the future. ${ }^{1-3}$ Currently, it is unknown how fast and in which ways these techniques will be used and whether they are a blessing or a curse. Regulations on scientific research vary within the European Union; as a result, scientists and consumers in each Member State have different approaches to and views on genetic analysis. ${ }^{4}$ Thus, consumers, scientist, physicians, ethicists, public health professionals, regulators and lawyers within the European Union now face the challenge of sorting through the various different methodologies and results produced.

In response to this growing problem and to the German government's request, the German Ethics Council ('Council') published 'The future of genetic diagnostics-from research to clinical application' ${ }^{2}$ on 30 April 2013, which could possibly establish a new benchmark in Europe. The opinion is meant to discuss the future of genetic diagnostic methods in relation to the current applicable laws and regulations as well as ethical stand points. Is the German Ethics Council's opinion setting a new trend in Europe?

In order to establish this opinion, the Council consulted experts in each single area, analyzed new developments, as well as the influence of genes in health and living in general, and genetic diagnostic methods. The Council's opinion reflects the most fundamental terms in genetics and epigenetics in the context of biology and the use in diagnostic, prognostic and predictive genetic analyses. Because genetic testing aims to discover the genetic cause for certain types of diseases, the Council's opinion sees not only the importance of bio-data banks for genetic tests regarding genotype and phenotype data banks and the influence of international collaborations, connected banks, but also the risk of monopolies in the private sector for certain types of genetic tests. ${ }^{6}$ The Council discusses the reliability of genetic tests as well as where genetic tests are used currently.

Genetic tests and analysis are highly sensitive methods not only from a scientific but also from a legal and ethical point of view., ${ }^{7,8}$ The Council's opinion highlights the importance of constitutionally guaranteed rights in Germany with regard to genetic tests. According to the Counsel, the most important constitutional rights relevant when speaking about genetic tests under the German Constitution are as follows: the constitutional right to live, the general right of personality, the principle of equality and prohibition of discrimination, which are as important to protect as academic freedom and the freedom of occupation. ${ }^{9}$ In addition to constitutionally guaranteed rights, the opinion describes the current applicable law for genetic tests in Germany: the German Gen Diagnostic Act ('GenDG'), the German Medicinal Devices Act ('MPG'), the German Embryo Protection Act ('ESchG'), dataprotection laws and the European directive on in vitro diagnostic medical devices 98/79/EC. Furthermore, the Counsel asserted that the existing data-protection laws in the single German states have different regulations regarding the research with personalized data, and this causes additional issues in international collaborations.

The opinion misses a critical analysis. Although this opinion pays close attention to the existing status quo, it fails to focus on the existing issues related to genetic tests and whether the current regulatory environment already solves the existing problems with regard to genetic tests, for example, the potential misuse of genetic test results by insures or the risk of disclosure toward employers. Furthermore, it does not address whether further regulatory steps taking ethical principles into account are necessary, except asking for broader information of the individual and the public about genetic tests. This leads incorrectly to the assumption that the currently

${ }^{1}$ CELLS - Center for Ethics and Law in the Life Sciences, Hannover, Germany

*Correspondence: Dr B Buechner, Center for Ethics and Law in the Life Sciences (CELLS), Leibniz Universitaet Hannover, Am Klagesmarkt 14-17, D - 30159 Hannover, Germany. E-mail: buechner@health-law.de

Received 25 May 2013; revised 14 September 2013; accepted 20 September 2013; published online 30 October 2013 
applicable law is sufficient. Reading further, the reader learns that the ethical analysis is changing the point of view.

The opinion examines the three major ethical issues related to genetic tests: the understanding of health; the understanding of autonomy, self-determination and responsibility; and the understanding of questions rose by the society and solidarism. ${ }^{10}$ The council distinguishes between the following aspects: information type (relevance to a disease?), odds that a phenotype appears, the expected date of appearance, severity of the health disorder, prevention or therapy, time of genetic test, relevance for the individual and reliance on the technique and validity. The Council argues that it has been discussed that a new status between health and sickness will be developed, which might influence social relationships in a negative way. Thus, the Council is asking for a comprehensive education about the uncertainty of the test results.

The right of self-determination is the key component in the discussion. Consumers have to be informed about their right to know and not to know the results of genetic tests. It has been argued that the right not to know does not exist in every situation; however, under certain circumstances, a researcher might have a duty to disclose certain results. In order to give full information, the Council recommends that it might be necessary to differentiate between the types of the genetic test and the necessary information to be given.

The Council suggests changing the way individuals are informed while focusing on types of diseases or health issues to be defined. Having said this, the Council recommends establishing a broad public education about genetic tests and diagnostic possibilities. In addition, cultural backgrounds shall be considered when informing individuals. The Council sees the continuing risk of stigmatization, even though the German GenDG prohibits discrimination against person because of genetic information in the work and insurance environment. In addition, the Council's opinion discusses issues related to an equal right to access the tests: the necessity to protect consumers in terms of direct-to-consumer testing not only on a national but also on an international level and genetic tests on minors as well as preimplantation diagnoses.

The Council's opinion concludes with 23 general recommendations on genetic tests and 9 recommendations regarding pre-implantation diagnostics. The 23 recommendations can be summarized as com prehensive education of the public and the individual and educating all physicians and not just specialists in genetic tests. Thus, different cultural backgrounds and the quantity of data gained from minors shall be questioned before actions are taken; the necessity of establishing the profession of a genetic consultant shall be discussed: no right to inform relatives of a certain disease without consent. Genetic sequencing should be regulated for more clarity, laboratories shall be accredited and the use in research shall be in accordance with UNESCO requirements.

With the 23 recommendations, the Council indirectly concluded that the existing regulations in Germany and thus indirectly on a European level do not protect consumers sufficiently. In the Council's point of view, broader information of individuals and the public as well as establishing the specialized profession of genetic counselors in Germany is the next step necessary in the right direction of consumer protection. Furthermore, the Council supports establishing new regulations for a more consumer-based protection approach because the pure existing ethical principles are not enforceable. It is important to be very clear that the established ethical principles have to be implemented into the law to bind individuals and legal entities.

The Council misses the opportunity for a broader overall analysis. It did not address which barriers might be necessary from legal and ethical points of view, which at the same time do not prohibit genetic testing and research. Thus, the Council's opinion is less trend setting in Europe than summarizing the current status quo in Germany besides fostering the discussion that the EU should regulate direct-toconsumer tests as one example.

\section{CONFLICT OF INTEREST}

The author declares no conflict of interest.

1 Ginsburg GS, Willard HF: Genomic and personalized medicine: foundations and applications. Trans/ Res 2009; 154: 277-287, referring the use of 'genomic medicine'.

2 Downing GJ: Key aspects of health system change on the path to personalized medicine. Trans/ Res 2009; 154: 272-276.

3 Ng PC, Murray SS, Levy S, Venter JC: Agenda for personalized medicine. Nature 2009; 461: 724-726.

4 Segolene A, Gribaldo L, Matthijs G et al: European Workshop on Genetic Testing Offer in Europe, JRC Scientific and Policy Reports 2013; http://ihcp.jrc.ec.europa. eu/our activities/public-health/jrc-publishes-a-report-entitled-genetic-testing-offerin-europe, last visited 14 September 2013.

5 The German Ethics Council's opinion is currently available in German only and can be downloaded at http://www.ethikrat.org/dateien/pdf/stellungnahme-zukunft-der-genetischen-diagnostik.pdf, last visited on 14 September 2013.

6 The German Ethics Council's opinion, p. 42 et. seq. at http://www.ethikrat.org/ dateien/pdf/stellungnahme-zukunft-der-genetischen-diagnostik.pdf, last visited on 14 September 2013 (Ger.).

7 Knoppers BM, Chadwick R: Human genetic research: emerging trends in ethics. Nat Rev Genet 2005; 6: 75-79.

8 Ayme S, Gribaldo L, Matthijs G et al: European Workshop on Genetic Testing Offer in Europe, JRC Scientific and Policy Reports 2013; http://ihcp.jrc.ec.europa.eu/our_ activities/public-health/jrc-publishes-a-report-entitled-genetic-testing-offer-in-europe, last visited 14 September 2013.

9 The German Ethics Council's opinion, p. 74 et. seq. at http://www.ethikrat.org/ dateien/pdf/stellungnahme-zukunft-der-genetischen-diagnostik.pdf, last visited on 14 September 2013 (Ger.).

10 The German Ethics Council's opinion, p. 112 et. seq. at http://www.ethikrat.org/ dateien/pdf/stellungnahme-zukunft-der-genetischen-diagnostik.pdf, last visited on 14 September 2013 (Ger.). 